\title{
Immunohistochemical Analysis of Gingival Proliferative Processes Associated with Fixed Orthodontic Therapy
}

\author{
CATALIN PETRU SIMON ${ }^{1}$, DANA CRISTINA BRATU ${ }^{2}$, ANDREI GHEORGHE MARIUS MOTOC ${ }^{1}$, \\ GEORGE POPA ${ }^{2}$, IZABELLA SILVIA POP ${ }^{3}$, OVIDIU ALEXANDRU MEDERLE ${ }^{4}$ \\ ${ }^{1}$ Victor Babes University of Medicine and Pharmacy, Faculty of Medicine, Department of Anatomy and Embryology, \\ 2 EftimieMurgu Sq., 300041, Timisoara, Romania \\ ${ }^{2}$ Victor Babes University of Medicine and Pharmacy, Faculty of Dental Medicine, Department of Orthodontics, \\ 9 Revolutiei din 1989 Blvd., 300070, Timisoara, Romania \\ ${ }^{3}$ University of Medicine, Pharmacy Sciences and Technology of Tirgu Mures, Faculty of Dental Medicine, Department \\ of Orthodontics, 38 Gheorghe Marinescu Str., 540139, Tirgu Mures, Romania \\ ${ }^{4}$ Victor Babes University of Medicine and Pharmacy, Faculty of Medicine, Department of Surgery I, Department of \\ Microscopic Morphology/Histology, Angiogenesis Research Center, 2 Eftimie Murgu Sq., 300041, Timisoara, Romania
}

\begin{abstract}
Our study started from the hypothesis that the gingival volume growth associated with fixed orthodontic treatment appeared during the use of leveling and aligning archwires, without any inflammatory signs, as a result of the mechanical stress and periodontal remodeling during the orthodontic dental movement.We selected and included in the study 35 patients (13 females and 12 males) between 12 and 38 years of age, all suffering from gingival overgrowth, diagnosed during the active treatment with fixed orthodontic appliances (braces). For each patient, two tissue samples were taken: one in the early stages of the lesion, coinciding with the use of leveling and aligning archwires and another in the late stages of the lesion, coinciding with the use of finishing archwires. The samples were taken from the same site in the oral cavity. Out of 35 gingival biopsies taken from patients, 8 cases showed no significant changes in the gingiva, while in the remaining 27 cases, significant changes were found after the histopathological exam.Out of 27 gingival biopsies, 16 cases presented a significantly greater number of T cells. In addition, a greater number of $B$ cells were observed in the granulation tissues than in the gingiva. The relative number of $B$ cells $(C D 20), T$ cells and dendritic cells (CD8) has been expressed, both in the early and the late stages of the gingival lesions. Our results revealed that the proportion of Tlymphocytes and dendritic cells was greater in the early stages rather than at the late stages. The B cells showed a higher count in the late stages.
\end{abstract}

Keywords: immunohistochemistry, histopathology, gingival overgrowth, fixed orthodontic treatment

Orthodontic treatment-induced gingival overgrowth shows a specific fibrous and thickened gingival appearance, different from fragile gingiva with marginal gingival redness which is seen in allergic or inflammatory gingival lesions [2]. However, there is no clear definition on its initiation and histopathology. Gingival overgrowth (GO) during the orthodontic treatment was traditionally considered as an inflammatory reaction consecutive to bacterial plaque accumulation because of difficult hygiene in those patients.

In this complex and adaptive immune process there are some special cells, like dendritic cells which play an important role and they can be potent antigen-capturing cells and antigen-presenting cells $[3,5]$.

The dendritic cells are involved in the immune homeostasis process they are susceptible to determine the dysregulation of chronic infections with severe systemic consequences [7,8].

In several immuno-inflammatory diseases, including periodontal disease, intracellular pathogens exploit the dendritic cells and escape degradation by avoiding autophagy $[9,10]$.

Orthodontic appliances induce mechanical stress in the periodontium, through the forces generated by the orthodontic archwires during active treatment [11].

\section{Experimental part}

Our study started from the hypothesis that the gingival volume growth associated with fixed orthodontic treatment appeared during the use of leveling and aligning archwires, without any inflammatory signs, as a result of the mechanical stress and periodontal remodeling during the orthodontic dental movement. For the patients in whom the gingival overgrowth was noticed, a gingivectomy was performed and the samples obtained were used for histologic and immunohistochemical examination.

\footnotetext{
*email: danacristinabratu@yahoo.com
} 


\section{Materials and methods}

In the present study, we selected and included 35 patients (13 females and 12 males) aged between $12-38$. The selected subjects were suffering from gingival overgrowth, covering one third or to two thirds of the clinical tooth crown, diagnosed during the active treatment with fixed orthodontic appliances (braces). For each patient, two tissue samples were taken: one in the early stages of the lesion, coinciding with the use of leveling and aligning archwires and another in the late stages of the lesion, coinciding with the use of finishing archwires. The samples were taken from the same site in the oral cavity.

All the patients underwent orthodontic treatment either in the Department of Orthodontics, Faculty of Dental Medicine, "Victor Babeș" University of Medicine and Pharmacy of Timișoara, Romania or in the private dental office.

All the patients signed the informed consent and samples were collected under the approval of the Ethical Committee of "Victor Babeș" University of Medicine and Pharmacy Timisoara. The selected patients were healthy, did not have any systemic diseases and none of them had taken medications that could affect their periodontal status.

\section{Clinical procedures}

The inclusion criteria- the absence of general diseases that may be associated with periodontal lesions with or without gingival overgrowth (GO) (e.g. diabetes, hematologic diseases, HIV infection, hypovitaminosis).

The patients that received, in the last month, general treatment with antibiotics, anti-inflammatory drugs, antiepileptic drugs and calcium antagonistswere excluded from the study.

\section{Orthodontic examination}

All the patients were diagnosed with dento-maxillary anomalies and were treated with fixed orthodontic appliances for a period of 1 to 3 years. For the orthodontic treatment we used a Roth prescription of Mini 2000 brackets (ORMCO), with a slot size of 0.022 inch. In the alignment phase we used 0.012-0.016-inch x 0.022-inch NiTi arch wires (ORMCO) and in the correction and finishing phase we used Sentalloy (Super Elastic Nickel Titanium Alloy, DENTSPLY GAC) and stainless-steel arch wires (ORMCO).

\section{Periodontal examination}

All the patients had good oral hygiene. The oral hygiene was assessed using the Simplified Oral Hygiene Index (OHI-S - Green and Vermillion, 1964). The Gingival Index (GI - Loe and Silness, 1963) and the Eastman Interdental Bleeding Index (EIBI) showed a normal gingival status for all the examined patients.

\section{Tissue sampling}

The patients underwent dental prophylaxis and were instructed to maintain proper oral hygiene. After a week, the patients were called for tissue sampling. The gingiva was cleaned and disinfected with a sterile compress moistened with $70 \%$ ethanol. A local anesthetic of Lidocaine 10\% spray was applied.

The excision of the interdental papillae or the volume-modified tissues (hyperplasic or hypertrophic tissues) was performed using a ceramic soft tissue trimer (Precicut, DFS DIAMON), similar to a high-speed dental FG bur. No water cooling was used. The soft tissue trimmer was inserted into a dental turbine and used at an operating speed of $300000 \mathrm{rpm}$. At high speeds, because of the friction between the tip of the instrument (made out of yttrium-stabilized nano-structure zirconia) and the tissue, the generated heat produced rapid tissue coagulation and almost complete hemostasis, without burning the tissue. The recovery time was much lower, and no healthy tissue was lost.

\section{Histopathology}

The samples were placed in hermetically sealed, sterile containers, in a $4 \%$ solution of formalin, after which they were stored in the refrigerator at a constant temperature of $4^{\circ} \mathrm{C}$. The samples were processed according to the paraffin inclusion technique. We performed the sections of the paraffin block, the deparaffinization, rehydration (or antigenic demasking in the case of immunohistochemistry technique) and the staining of smears.

The deparaffinization protocol involved carrying out three successive benzene baths, 5 minutes each, followed by two successive $100 \%$ ethanol baths, one $95 \%$ ethanol bath and one $70 \%$ ethanol bath, 2 minutes each.

The rehydration was performed by rinsing the samples with distilled water in two successive baths.

Hematoxylin/Eosin (H\&E) stain protocol was used for the histopathological examination.

Staining, regardless of the chosen technique, is followed by dehydration in three ethanol baths in increasing concentrations and by clarification in three benzene baths.

\section{Immunohistochemistry}

The specimens were fixed in $10 \%$ buffered formalin for 48 hours and embedded in paraffin. The paraffinembedded tissues were cut into $5 \mu \mathrm{m}$ sections. All the samples were stained using the H\&E stain protocol. We 
performed an enzyme pretreatment (Bond Enzyme Pretreatment Kit, Leica Biosystems, Newcastle upon Tyne, UK) for 10 minutes. Endogenous peroxidase blocking was done with 3\% hydrogen peroxide for 5 minutes. This step was followed by incubation for 15 minutes with CD8 and CD20 (Novocastra, Newcastle upon Tyne, UK, rabbit polyclonal antibodies, ready to use) as primary antibodies. We utilized a set of clusters of differentiation (CD) antigen-specific monoclonal antibodies to detect different cell types within the tissues. These included anti-CD20 (B cells), anti-CD8 (suppressor T cells and dendritic cells).

The Bond Polymer Refine Detection System (Leica Biosystems, Newcastle upon Tyne, UK) was used for visualization. The 3.3-diaminobenzidine-dihydrochloride was applied as chromogen and we used hematoxylin for counterstaining. The entire immunohistochemical procedure was developed with Leica Bond-Max (Leica Biosystems, Newcastle upon Tyne, UK) autostainer. Image acquisition and analysis were performed using Nikon Eclipse E600 microscope and Lucia G software for microscopic image analysis.

\section{Results and discussions}

Out of 35 gingival biopsies taken from patients, 8 cases showed no significant changes in the samples, while in the remaining 27 cases, significant changes were found after the histopathological exam.

The histopathological examination of the gingival specimens, in 27 cases, revealed a parakeratinized surface epithelium of the attached gingiva of variable thickness in different parts, connective tissue stroma formed of longitudinal bundles of hyalinized delicate collagen fibrils, which showed various distributions, either dense or finely arranged. They were interspersed with a heavy chronic inflammatory infiltrate (mainly lymphocytes and plasma cells) and a significant number of dilated blood vessels. Orthodontic treatment-induced gingival overgrowth showed firm and pink tissue enlargements with no tendency to bleeding. Histological examination of the gingiva showed a wellstructured and thickened epithelium, with elongated and very thick papillae inserted in fibrous connective tissue. The connective tissue showed thick collagen fiber bundles.

The histopathological examination showed a dense band of subepithelial collagenous fibrous tissue. We also observed a zone heavily infiltrated with chronic inflammatory cells packed with plasma cells, lymphocytes and fewer dilated blood vessels.

Out of 27 gingival biopsies, 16 cases presented a significantly greater number of $T$ cells. In addition, a greater number of B cells were observed in the granulation tissues than in the gingiva.

In this type of progressive lesions induced by orthodontic treatment, the relative number of B cells (CD20), T cells and dendritic cells (CD8) has been expressed, both in the early and the late stages of the gingival lesions. Our results revealed that the proportion of $\mathrm{T}$ lymphocytes and dendritic cells was greater in the early stages rather than in the late stages (Fig. 1 and 2). The B cells showed a higher count in the late stages (Fig. 3 and 4).

The dendritic cells migrated from the basal stratum towards the epidermal superficial stratum.

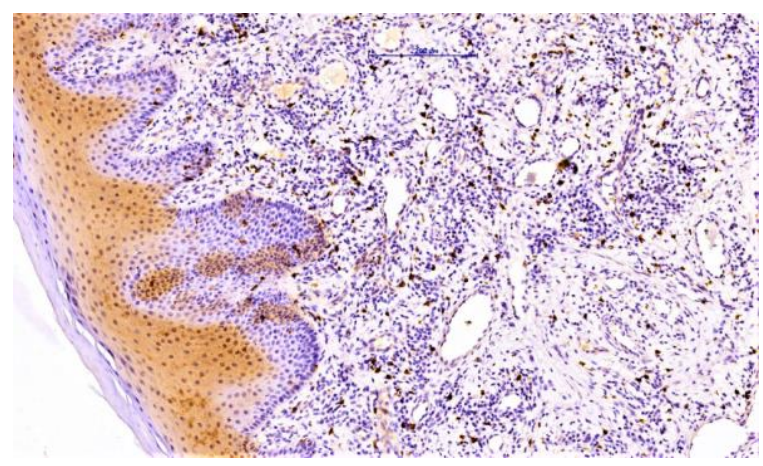

Fig. 1. Dendritic cells and T lymphocytes, CD8+ exhibited a diffuse distribution, immunostaining, ob. x20

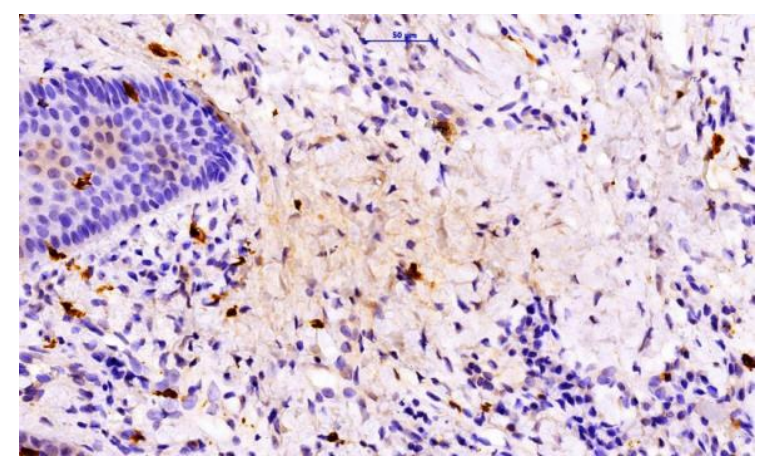

Fig. 2. Dendritic cells from the basal layer of the epithelium and T lymphocytes, CD8+, immunostaining, ob. $x 40$ 


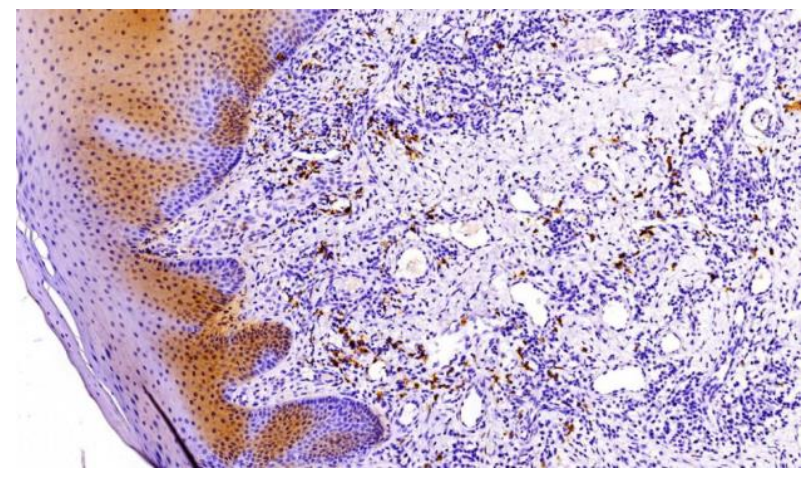

Fig. 3. CD20+ (B lymphocytes) cell distribution was present predominantly in groups in inflammatory infiltrate, immunostaining, ob. x20

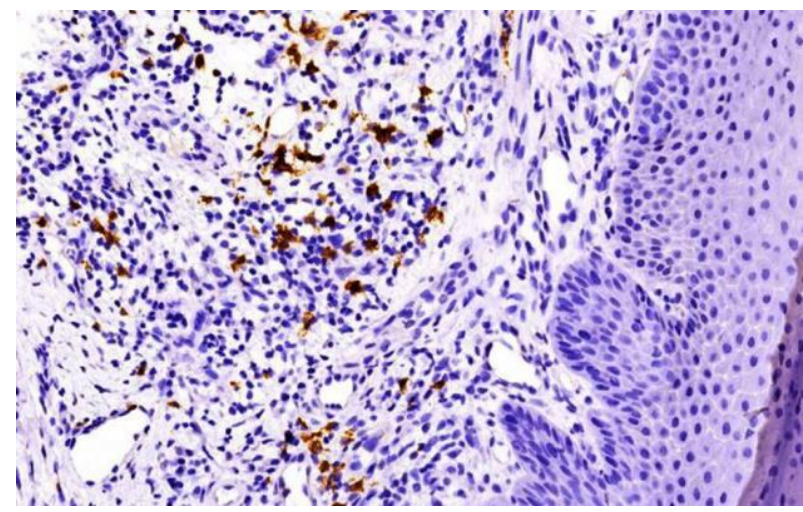

Fig. 4. CD20+ (B

lymphocytes) cell distribution was predominantly in a focal distribution, immunostaining, ob. $x 40$

Orthodontic therapy-induced gingival overgrowth was associated with a prominent epithelial proliferation response. This process was supported by increased collagen fiber bundles, resembling several overgrowth types such as drug-related gingival enlargement $[6,7,12,13]$.

Some differences have been observed between the analysis of gingival overgrowth and chronic inflammatory gingival enlargements associated with plaque accumulation around orthodontic appliances. Gingival overgrowth lacks exudative and proliferative characteristics of chronic inflammation [14].

Orthodontic therapy-related gingival overgrowth was characterized by fibrous, thick and pink tissues that showed no tendency to bleeding, compared to the clinically observed deep red, soft, fragile, easily bleeding lesions, which are common in allergic or inflammatory gingival enlargements $[2,13,14]$.The biopsies were taken from the buccal part of the interdental papilla, whom inflammation is a very common symptom during orthodontic treatment. Banded molars, during the orthodontic treatment showed more clinical signs of gingival inflammation than those of untreated individuals. Moreover, major risk factors identified included the presence of plaque and the presence of subgingival band margins [1,4].

Orthodontic treatment may initiate oral clinical manifestations, such as labial desquamation [15], gingival enlargement [16,17,18], multiform erythema [19] and gingivitis [20].

These manifestations are usually associated with the inflammatory response induced by the corrosion of orthodontic appliances and the nickel release has been considered of great importance [21].

The inflammatory response to nickel is considered type IV hypersensitivity and is manifested as nickel allergic contact stomatitis [22,23]. Gingival enlargement is a more common side effect of orthodontic treatment than other manifestations in the oral cavity [14,17], but the fibrous gingival enlargements associated with fixed orthodontic appliances seem to be transitory [13].

\section{Conclusions}

In our study we observed that in early stages of progressive lesions during orthodontic treatment, $\mathrm{T}$ and dendritic cells numbers were increased, while in the late stages we noticed a higher count of the B cells.

\section{References}

1. REDLICH M, SHOSHAN S, PALMON A. Am J OrthodDentofacialOrthop, 1999; 116(2):152-8.

2. RAMADAN AA. World J. Orthod., 5, no. 3, 2004; p. 230-234, 235.

3. DE WITTE, L., NABATOV, A., PION, M., FLUITSMA, D., DE JONG, M.A.W.P., DE GRUIJL, T., PIGUET, V., VAN KOOYK, Y., GEIJTENBEEK, T.B.H., Nat. Med., 13, no. 3, 2007; p. 367-71.

4. CORBACHO DE MELO MM, CARDOSO MG, FABER J, SOBRAL A. Angle Orthod, 2012; 82(2):224-8.

5. FACCIONI, F., FRANCESCHETTI, P., CERPELLONI, M., FRACASSO, M.E., Am. J. Orthod. Dentofac. Orthop., 124, no. 6, 2003; p. 68793.

6. VIPIN BHARTI, CHHAYA BANSAL. J Indian Soc Periodontol, 2013 Mar-Apr; 17(2): 182-87.

Rev. Chim. $72 \downarrow$ no. $2 \bullet 2020 \bullet$ https://revistadechimie.ro 
7. ROI, C.I., GAJE, P.N., CEAUSU, R.A., POPOVICI, R.A., RAICA, M., Rev. Chim., 2018; 69, no. 1, p. $232-5$.

8. CUTLER, C.W., JOTWANI, R., J. Dent. Res., 85, no. 8, 2006; p. 678-89.

9. AHMED R. EL-AWADY, ROGER M. ARCE, CHRISTOPHER W. CUTLER. Periodontol 2000, 2015 Oct; 69(1): 160-80.

10. VAN KOOYK, Y., ENGERING, A., LEKKERKERKER, A.N., LUDWIG, I.S., GEIJTENBEEK, T.B.H., Curr. Opin. Immunol., 2004; 16, no. 4, p. 488-93.

11. POP, S.I., DUDESCU, M., BRATU, D.C., MERIE, V.V., PACURAR, M., Rev. Chim., 66, no. 3, 2015; p. $364-7$.

12. ANCUTA, C., ANCUTA, E., CHIRIEAC, R., ANTON, C., SURLARI, Z., IORDACHE, C., Rev. Chim., 68, no. 8, 2017 ; p. $1914-8$.

13. CARRANZA, F.A., HOGAN, E.L. Carranza's Clinical Periodontology, 11th edition, Elsevier Saunders, NEWMAN, M.G., TAKEI, H.H., KLOKKEVOLD, P.R., CARRANZA, F.A. (eds.), Philadelphia, 2006; p. 84-96.

14. GURSOY, U.K., SOKUCU, O., UITTO, V.J., AYDIN, A., DEMIRER, S., TOKER, H., ERDEM, O., SAYAL, A., Eur. J. Orthod., 2007; 29, no. 6, p. 555-8.

15. VIJAYAN V., PAUL A, BABU K., MADHA B. J Indian Soc Periodontol, 2016 May-Jun; 20(3):340-3.

16. PONNAM SR, SRIVASTAVA G, JAMPANI N, KAMATH VV. J Oral MaxillofacPathol, 2014; 18:121-6.

17. GENELHU, M.C.L.S., MARIGO, M., ALVES-OLIVEIRA, L.F., MALAQUIAS, L.C.C., GOMEZ, R.S., Am. J. Orthod. Dentofac. Orthop., $2005 ; 128$, no. 3, p. 378-81.

18. KOURAKI, E., BISSADA, N.F., PALOMO, J.M., FICARA, A.J., N.Y. State Dent. J., 2005; 71, no. 4, p. 34-7.

19. LUIS PAULINO, DAVID J HAMBLIN, NGOZI OSONDU, RICHARD AMINI. Cureus, 2018 Oct; 10(10): e3459.

20. BAYGIN O., TUZUNER T., OZEL M.B., BOSTANOGLU O. Medicina Oral, Patologia Oral y Cirugia Bucal, 2013; vol. 18, no. 2, pp. e362-e370.

21. ELIADES, T., TRAPALIS, C., ELIADES, G., KATSAVRIAS, E. Eur. J. Orthod, 2003; 25, no. 1, p. 103-6.

22. MINCIULLO PAOLA LUCIA, PAOLINO GIOVANNI, VACCA MADDALENA, GANGEMI SEBASTIANO, NETTIS EUSTACHIO. Clin Mol Allergy, 2016; 14(1): 10.

23. RAI R, DINAKAR D, KURIAN SS, BINDOO YA. Indian Dermatol Online J, 2014 Jul; 5(3): 282-6.

$\overline{\text { Manuscript received: } 3.12 .2019}$ 